\title{
Evaluation of Optokinetic Nystagmus Asymmetry in Surgically Treated Infantile Esotropia Patients
}

\section{Cerrahi Uygulanmış Infantil Ezotropyalı Hastalarda Optokinetik Nistagmus Asimetrisi Değerlendirilmesi}

\author{
(- Sadık Etka Bayramoğlu, @ Zafer Cebeci* \\ University of Health Sciences, Kanuni Sultan Süleyman Training and Research Hospital, Clinic of Ophthalmology, Istanbul, Turkey \\ *istanbul University Istanbul Faculty of Medicine, Department of Ophthalmology, Istanbul, Turkey
}

Abstract

Aim: To evaluate the relationship between binocularity and optokinetic nystagmus asymmetry (OKN) in patients with infantile esotropia.

Methods: The study design was prospective and cross-sectional. Ten patients who underwent surgery for infantile esotropia between 1982 and 2010 in the Department of Ophthalmology of the İstanbul University, İstanbul Faculty of Medicine were included in the study. The patients underwent complete ophthalmic examination including spherical equivalent, deviation angle, simultaneous perception (SP) and OKN stimulation. The patients were grouped according to the SP grades. The ratio of temporo-nasal (TN) OKN frequency to nasotemporal (NT) OKN frequency was compared between the SP-positive and negative-groups.

Results: In the SP-negative group, the mean number of TN and NT amplitudes and the ratio of number of TN/NT amplitudes were 26.20 $\pm 9.31,11.40 \pm 5.59$, and 2.42 \pm 0.77 , respectively. In the SPpositive group, the mean number of TN and NT amplitudes and the ratio of number of TN/NT amplitudes were $29.40 \pm 10.64,17.60 \pm 8.08$, and $1.82 \pm 0.57$, respectively. When both groups were compared, the detected $p$ values were $0.91,0.29$ and 0.24 , respectively.

Conclusions: We detected lower OKN asymmetry in the low-grade binocularity group compared to that in binocularity-negative group. We think that these findings did not reach a statistically significant level due to the limited number of patients enrolled in our study.

Keywords: Infantile esotropia, strabismus, optokinetic nystagmus, binocularity
Öz

Amaç: Infantil ezotropyalı hastalarda optokinetik nistagmus (OKN) asimetrisi ile binokülarite arasındaki ilişkiyi incelemektir.

Yöntemler: Prospektif, kesitsel bir çalışmadır. Çalışmaya 1982 ile 2010 yılları arasında infantil ezotropya nedeniyle İstanbul Üniversitesi İstanbul Tıp Fakültesi'nde cerrahi uygulanan 10 hasta çalışmaya dahil edildi. Hastalara sferik eş değer, kayma açısı, simultane persepsiyon (SP) testi ve OKN uyarımı testini içeren tam bir göz muayenesi yapıldı. Hastalar SP düzeyine göre gruplandırıld. SP saptanan grup ile saptanmayan grup arasında temporo-nazal (TN) OKN frekansının, nazo-temporal (NT) OKN frekansına oranı karşılaştıııldı.

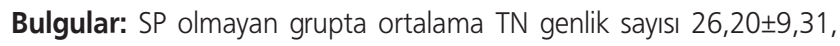

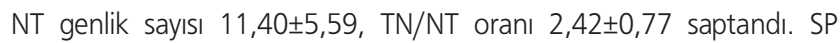
olan grupta ortalama TN genlik sayısı $29,40 \pm 10,64$, NT genlik sayısı $17,60 \pm 8,08$, TN/NT oranı 1,82 $\pm 0,57$ saptandı. Her iki grup arasında TN genlik sayısı, NT genlik sayısı ve TN/NT oranı karşılaştıııldı̆ında $p$ değerleri sırası ile 0,91, 0,29 ve 0,24 olarak bulundu.

Sonuç: Düşük derece binokülarite olan grupta binokülarite olmayan gruba göre daha az OKN asimetrisi saptadık. Çalışmamızın hasta sayısının azlığı ile ilgili sınılamalarından dolayı bu bulguların istatistiksel olarak anlamlı seviyeye ulaşmadığını düşünmekteyiz.

Anahtar Sözcükler: İnfantil ezotropya, şaşılık, optokinetik nistagmus, binokülarite
Address for Correspondence/Yazışma Adresi: Sadık Etka Bayramoğlu

University of Health Sciences, Kanuni Sultan Süleyman Training and Research Hospital, Clinic of Ophthalmology, İstanbul, Turkey Phone: +90 5053363241 E-mail: sadiketka@windowslive.com ORCID ID: orcid.org/0000-0002-9502-4368

Received/Geliş Tarihi: 29 March 2018 Accepted/Kabul Tarihi: 26 June 2018
${ }^{\circ}$ Copyright 2019 by The Medical Bulletin of University of Health Sciences Haseki Training and Research Hospital

The Medical Bulletin of Haseki published by Galenos Yayınevi.

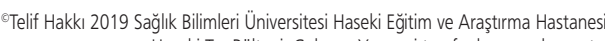
Haseki Tip Bülteni, Galenos Yayınevi tarafından yayınlanmıştır. 


\section{Introduction}

Infantile esotropia (IE) is a manifest esotropia occurring in the first six months of life with a large angle of deviation and low-moderate hyperopia (1). IE is not accompanied by systemic and neurological disorders (1). The prevalence of IE has been reported to be between $0.25 \%$ and $0.5 \%$ (1-3). Amblyopia, abduction deficit, excessive adduction, dissociated vertical deviation, dissociated horizontal deviation, A-V pattern, manifest-latent nystagmus, asymmetric optokinetic nystagmus (OKN), and anomalous head posture findings may be accompanied at the time of diagnosis or later (1).

During pursuit of the OKN drum, smooth tracking eye movements (slow phase) occur in the direction of the moving strips; in the opposite direction of the strip, corrective saccadic eye movements occurs (quick phase) (4). In normal individuals, pursuit movements have equal facility independent from the movement direction of the strip.

Normal and equal binocular visual stimuli are needed in the infantile period for the development of optokinetic reflex. Symmetrical pursuit eye movement is disturbed by the immaturity resulting from the failure of stimulation in IE patients. As the drum moves in the naso-temporal (NT) direction, pursuit eye movements become irregular, or no pursuit eye movements occurs (5).

In this study, we evaluated the presence and severity of OKN asymmetry in surgically treated IE patients with lowgrade binocularity and with no measurable binocularity. We aimed to determine whether there was a relationship between binocularity and OKN asymmetry in IE patients.

\section{Methods}

The study was designed as a prospective and crosssectional study. Ten patients, who underwent surgery for IE between the years 1982 and 2010 in the department of ophthalmology of the İstanbul University istanbul Faculty of Medicine, were included the study. Written informed consent was obtained from legal representatives of all participants who were involved in the study. The study was conducted in accordance with the approval of the ethics committee of İstanbul University İstanbul Faculty of Medicine (approval number: 2012/1499-1226) and the principles of the Helsinki Declaration.

At the last visit, complete ophthalmic examination, including spherical equivalent (SE), deviation angle and simultaneous perception tests, were performed for all participants.

OKN stimulation and analysis of eye movements were performed using vision monitor equipment (Metrovision, Perenchies, France). Visual stimuli were produced on a monitor measuring $51 \mathrm{~cm}$ diagonally placed $40 \mathrm{~cm}$ away from the patient (frame rate $120 \mathrm{~Hz}$ ). The screen's visual field dimensions were $54^{\circ}$ horizontal and $4^{\circ}$ vertical. OKN was stimulated with alternate black (luminance $1 \mathrm{~cd} / \mathrm{m}^{2}$ ) and white (luminance $70 \mathrm{~cd} / \mathrm{m}^{2}$ ) vertical stripes of $2^{\circ}$ visual angle (corresponding to 20/2400 visual acuity). The strips were monocularly formed for 40 seconds with 2-minute intervals in the temporo-nasal (TN) or NT direction at constant velocities (6-9). The patients were instructed to look at the centre of the monitor to elicit stare nystagmus without following the stripes. Eye movements were recorded by measuring the position of the corneal reflex relative to the centre of the pupil with a near infrared illumination of the eye $(880 \mathrm{~nm})$. Therefore, the recorded eye movements were not affected by the head movement. Sampling rate was $60 \mathrm{~Hz}$ with a resolution of 10 minutes of arc.

The method of quantifying the OKN asymmetry with videoculography was as follows: The comparison was made by analyzing the six-second record of the most regular optokinetic response for each patient; if there was alternation and there was no amblyopia, the eye with better measurement quality was included in the study. If there was no alternation, measurement was taken from the eye showing fixation preference. Regardless of the amplitude of the eye movement, only the total number of eye movements per unit time was analyzed. The TN/NT ratio for each eye was calculated by dividing the TN frequency by the NT frequency (Figure 1). The OKN asymmetry rates were compared between the simultaneous perception (SP)-positive and negative-groups.
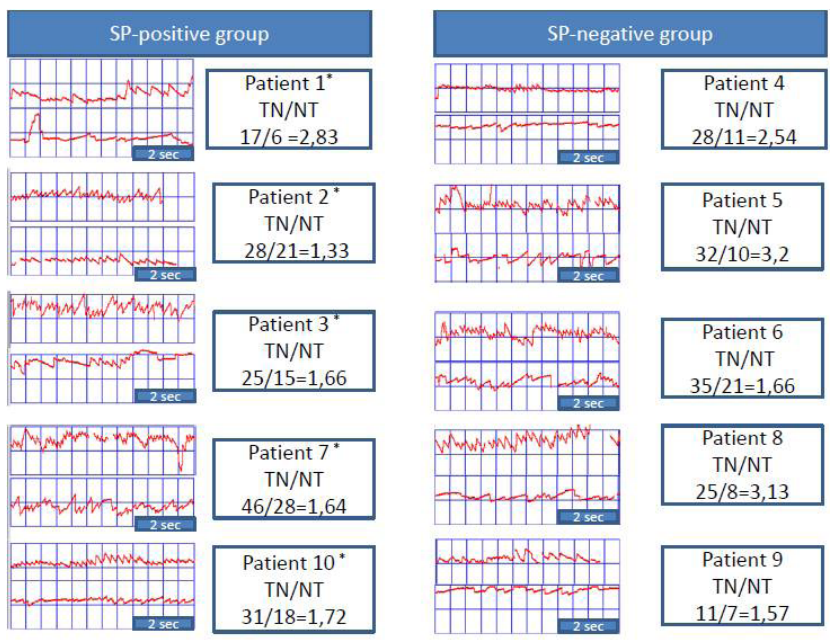

Figure 1. Optokinetic nystagmus (OKN) records of each patient were presented separately. OKN records of simultaneous perception (SP) positive group are presented in the left column. OKN recordings of SP-negative group are presented in the right column. Temporo-nasal OKN records are showed on the upper side, naso-temporal OKN records are showed on the lower side of the each record

TN/NT: Temporo-nasal/naso-temporal 
SP examination was performed with a synoptophore device (Clement Clarke, Haag-Streit UK). The slides (slide no. G3-G4) containing a lion and a cage figure were shown. Patients, who perceive the lion inside the cage, were recorded as having a simultaneous perception.

\section{Statistical Analysis}

Statistical analysis was done using the SPSS 18.0 (SPSS for Windows, Chicago, USA) software. Data from two groups were compared using the Mann-Whitney $U$ test. A $p$ value of $\leq 0.05$ was considered statistically significant.

\section{Results}

Seven (70\%) of the ten patients were male and three were female. The mean follow-up period was $113.2 \pm 69.64$ (12-210) months. The mean age of the patients at the first visit was $23.1 \pm 8.81$ (8-36) months. The mean deviation angle at the first visit was $44.80 \pm 15.24$ (30-80) prism diopters. The mean age at surgery was $42.50 \pm 14.30$ (2768) months. The mean SE at the preoperative examination was $1.95 \pm 2.04(-2.13-5.00)$ diopters. The mean age of the patients at the last visit was 155.70 \pm 68.48 (46-244) months. The mean SE at the last visit was 1.72 \pm 2.67 (-2.94$5.25)$ diopters. The mean deviation angle at the last visit was $8.9 \pm 5.30$ (0-15) prism diopters. Other examination findings are listed in Table 1. Comparisons of patients with and without SP are presented in Table 2.

In the SP-negative group, the mean number of TN amplitudes was $26.20 \pm 9.31$, the mean number of NT amplitudes was $11.4 \pm 5.59$, and the mean ratio of the number of TN/NT amplitudes was $2.42 \pm 0.77$. In the SP-positive group, the mean number of TN amplitudes was $29.40 \pm 10.64$ and mean number of NT amplitudes was $17.60 \pm 8.08$. The mean ratio of the number of TN/ NT amplitude was $1.82 \pm 0.57$. The difference was not statistically significant $(p=0.24)$ (Table 3 ).

\section{Discussion}

It has been shown that the measurement of OKN was affected by target stimulus size, shape, contrast, velocity, recording techniques and working distance. Die and

\begin{tabular}{|c|c|c|c|c|c|}
\hline & $\mathbf{N}$ & Mean & Standard deviation & Minimum & Maximum \\
\hline Age at first visit (months) & 10 & 23.10 & 8.812 & 8 & 36 \\
\hline Deviation angle at first visit (prism diopters) & 10 & 44.80 & 15.245 & 30 & 80 \\
\hline Age at surgery (months) & 10 & 42.50 & 14.308 & 27 & 68 \\
\hline Deviation angle at preoperative visit & 10 & 43.40 & 15.665 & 30 & 80 \\
\hline SE at preoperative visit & 10 & 1.9500 & 2.04905 & -2.13 & 5.00 \\
\hline Age at last visit (months) & 10 & 155.70 & 68.484 & 46 & 244 \\
\hline Deviation angle at last visit (prism diopters) & 10 & 8.90 & 5.301 & 0 & 15 \\
\hline SE at last visit & 10 & 1.7250 & 2.67580 & -2.94 & 5.25 \\
\hline Follow-up time (months) & 10 & 113.2000 & 69.64162 & 12.00 & 210.00 \\
\hline
\end{tabular}

Table 2. Comparison of both groups

\begin{tabular}{|l|l|}
\hline & SP-negative group (n=5) \\
\hline Age at first visit (months) & $25.20 \pm 9.88(12-36)$ \\
\hline Deviation angle at first visit (prism diopters) & $38.6 \pm 6.84(34-50)$ \\
\hline Age at surgery (months) & $45 \pm 13.47(33-66)$ \\
\hline SE at preoperative visit & $1.92 \pm 1.95(0-5.00)$ \\
\hline Age at last visit (months) & $180.6 \pm 67.60(78-244)$ \\
\hline SE at last visit & $1.56 \pm 3.23(-2.94-5.25)$ \\
\hline Deviation angle at last visit (prism diopters) & $10.20 \pm 6.01(0-15)$ \\
\hline Follow-up time (months) & $135 \pm 67.96(29-210)$ \\
\hline SE: Spherical equivalent, SP: Simultaneous perception, *Mann-Whitney U test
\end{tabular}

\begin{tabular}{|l|l|}
\hline SP-positive group $(\mathbf{n}=5)$ & $\mathbf{p}^{*}$ value \\
\hline $21.00 \pm 8.12(8-27)$ & 0.484 \\
\hline $51.00 \pm 19.49(30-80)$ & 0.216 \\
\hline $40 \pm 16.23(27-68)$ & 0.611 \\
\hline $1.97 \pm 2.36(-2.13-3.50)$ & 0.972 \\
\hline $130.8 \pm 66.57(46-225)$ & 0.274 \\
\hline $1.88 \pm 2.35(-1.31-4.44)$ & 0.861 \\
\hline $7.60 \pm 4.77(0-12)$ & 0.471 \\
\hline $90.80 \pm 70.98(12-186)$ & 0.338 \\
\hline
\end{tabular}




\begin{tabular}{|l|l|l|l|}
\hline \multicolumn{2}{|l|}{ Table 3. Comparison of optokinetic nystagmus responses in both groups } & ' \\
\hline & SP-negative group (n=5) & SP-positive group (n=5) \\
\hline The mean number of TN amplitudes (In 6-second recording) & $26.20 \pm 9.31(11-35)$ & $29.40 \pm 10.64(17-46)$ \\
\hline The mean number of NT amplitudes (In 6-second recording) & $11.40 \pm 5.59(7-21)$ & $17.60 \pm 8.08(6-28)$ & 0.91 \\
\hline Ratio of TN/NT amplitudes & $2.42 \pm 0.77(1.57-3.20)$ & $1.82 \pm 0.57(1.33-2.83)$ & 0.24 \\
\hline TN: Temporo-nasal, NT: Naso-temporal, SP: Simultaneous perception, *Mann-Whitney U test & & 0.29 \\
\hline
\end{tabular}

Collewijn (10) investigated the effect of light intensity and visual field defects on OKN. They have reported that OKN gain was decreased in scotopic conditions. Under scotopic conditions, central physiological (scotopic) scotomas were formed because the vision is mainly provided by the rods. Additionally, it has been shown that horizontal OKN gain decreased in patients with age-related macular degeneration (AMD) who had pathological central scotomas (10). Valmaggia et al. (6) investigated the effect of central scotoma size on OKN gain in AMD patients and showed that OKN gain did not change in patients with $1^{\circ}-10^{\circ}$ and $10^{\circ}-20^{\circ}$ central scotomas, but decreased in patients with larger central scotomas as $20^{\circ}-30^{\circ}$. Leguire et al. (11) reported a symmetric and similar changes in TN OKN or NT OKN according to the change in contrast sensitivity. Due to small number of patients, different eye movement recording systems and inadequate measurement techniques in the reported series cause difficulties in obtaining an accurate comparison and a definite conclusion (12).

All OKN types, such as horizontal, vertical and torsional, show a response with a slow tracking phase followed by a rapid resetting saccade. Horizontal OKN is the most widely researched OKN form and it was widely accepted that horizontal OKN asymmetry does not develop in normal healthy adults (13). OKN asymmetry in favor of TN versus NT has been reported in normal neonates during the first four months of life (14). OKN asymmetry develop not only in strabismic patients, but may also develop in patients who do not have a binocular stimulation after any condition causing monocular visual deprivation early in life, such as anisometropia or enucleation $(15,16)$. For this reason, optokinetic asymmetry is a manifestation of the motion processing defect in visual pathways as a primary rather than a component of essential IE.

The onset of visual loss plays an important role in the development of OKN asymmetry. It has been reported that OKN asymmetry was not detected in children who had profound visual loss in one eye from birth and who developed visual loss after three years of life $(17,18)$. Shawkat et al. (18) compared the optokinetic response between monoocular patients with total visual loss in one eye and patients with decreased vision in one eye. OKN asymmetry was not detected in patients who were completely monocularly blind (profound visual loss) from birth, but monocular aphakic infants (non-profound unilateral visual deprivation) showed OKN asymmetry. The group, defined as profound vision loss, consisted of two microphthalmia and four unilateral inoperable primary persistent hyperplastic vitreous patients diagnosed during the first week of life. The reported visual acuity was light perception in four patients and no light perception in two patients. The group, defined as non-profound vision loss, consisted of ten patients who underwent early surgery for congenital cataract and who had visual acuities better than $1 / 60$. These findings show that OKN asymmetry does not develop in individuals who were monocular from birth due to the lack of any competition between two eyes. In strabismic and amblyopic individuals, it has been stated that abnormal binocular competition between the two eyes results in an asymmetric OKN response $(16,18)$. It has been reported that monocular OKN persists after enucleation performed for retinoblastoma or Coats' disease (16). In that study, enucleation age ranged from 5 to 67 months. It should be emphasized that, these patients should be accepted as having non-profound visual loss, since patients have visual stimulation before enucleation. In their study, Westall and Shute (19) reported that while in early onset strabismus subjects (before 24 months of age) OKN asymmetry rate was $73 \%$, it was $42 \%$ in patients with later onset strabismus. In a subsequent study, it was observed that IE patients all had OKN asymmetry (20).

In animal studies, it has been showed that pursuit eye movements in the NT direction were associated with binocular cells in the visual cortex and the ipsilateral nucleus of optic tractus (21). TN follower pathways are binocularly independent (22). The fact that the TN follower pathways are binocularly independent seems to be the reason why TN follow-up movement is not affected in the absence of binocularity (22). Hoffmann (23) hypothesized that TN OKN occurs with subcortical projections and NT OKN occurs with cortical projections to the pretectal nucleus of the optic tract and the dorsal terminal nucleus of the accessory optic system. In early 
life, first subcortical projections develop which dominates TN OKN. Later, in normal subjects, development of cortical projections supports NT OKN. If cortical projections did not developed due to disruption of binocularity for any reason, inadequate NT OKN response occurs. In patients with stereopsis loss, a relationship has been found between the severity of OKN asymmetry and the binocular visual field affected $(23,24)$.

In a study of strabismic patients, significant OKN asymmetry was detected in patients without binocularity, while OKN asymmetry was not detected in low binocularity group but decreased OKN gain was detected (8). Additionally, it was determined that patients with early onset strabismus had more OKN asymmetry. These results support that OKN gain and asymmetry are associated with development of binocular vision.

It has been reported that OKN asymmetry continues even if strabismus is corrected surgically and there is no residual amblyopia (25). In contrast to this report, Westall and Shute (19) reported a slight reduction in OKN asymmetry after occlusion therapy in the amblyopic eye. This result supports our results, although the results of our study were not statistically significant.

\section{Conclusion}

In conclusion, difficulties due to OKN response assessment techniques, reproducibility of our study decreases. Limitations of our study include neglecting the amplitude magnitude and analyzing OKN using only six-second recording. The low number of patients in this study makes it difficult to obtain statistically significant results. However, detection of lower OKN asymmetry in the IE group with low-grade binocularity in our study may be meaningful if supported by future studies with larger sample sizes.

\section{Authorship Contributions}

Surgical and Medical Practices: S.E.B., Z.C. Concept: S.E.B., Z.C. Design: S.E.B., Z.C. Data Collection or Processing: S.E.B. Analysis or Interpretation: S.E.B., Z.C. Literature Search: S.E.B., Z.C. Writing: S.E.B., Z.C.

Conflict of Interest: No conflict of interest was declared by the authors.

Financial Disclosure: The authors declared that this study received no financial support.

\section{References}

1. Costenbader FD. Infantile esotropia. Trans Am Ophthalmol Soc 1961;59:397.

2. Friedman Z, Neumann E, Hyams SW, Peleg B. Ophthalmic screening of 38,000 children, age 1 to $21 / 2$ years, in child welfare clinics. J Pediatr Ophthalmol Strabismus 1980;17:261-7.
3. Nixon RB, Helveston EM, Miller K, Archer SM, Ellis FD. Incidence of strabismus in neonates. Am J Ophthalmol 1985; 100:798-801.

4. Garbutt S, Han Y, Kumar AN, Harwood M, Harris CM, Leigh RJ. Vertical optokinetic nystagmus and saccades in normal human subjects. Invest Ophthalmol Vis Sci 2003;44:3833-41.

5. Schor CM, Levi DM. Disturbances of small-field horizontal and vertical optokinetic nystagmus in amblyopia. Invest Ophthalmol Vis Sci 1980;19:668-83.

6. Valmaggia C, Charlier J, Gottlob I. Optokinetic nystagmus in patients with central scotomas in age related macular degeneration. Br J Ophthalmol 2001;85:169-72.

7. Valmaggia C, Gottlob I. Optokinetic nystagmus elicited by filling-in in adults with central scotoma. Invest Ophthalmol Vis Sci 2002;43:1804-8.

8. Valmaggia C, Proudlock F, Gottlob I. Optokinetic nystagmus in strabismus: are asymmetries related to binocularity? Invest Ophthalmol Vis Sci 2003;44:5142-50.

9. Valmaggia $C$, Rütsche A, Baumann A, et al. Age related change of optokinetic nystagmus in healthy subjects: a study from infancy to senescence. Br J Ophthalmol 2004;88:157781.

10. Van Die GC, Collewijn H. Control of human optokinetic nystagmus by the central and peripheral retina: effects of partial visual field masking, scotopic vision and central retinal scotomata. Brain Res 1986;383:185-94.

11. Leguire L, Zaff B, Freeman S, et al. Contrast sensitivity of optokinetic nystagmus. Vision Res 1991;31:89-97.

12. Knapp CM, Proudlock FA, Gottlob I. OKN asymmetry in human subjects: a literature review. Strabismus 2013;21:3749.

13. Garbutt S, Harris C. Major review-A review of optokinetic nystagmus $(\mathrm{OKN})$ in infants and children. Br Orthopt J 1999:1-10.

14. Naegele JR, Held R. The postnatal development of monocular optokinetic nystagmus in infants. Vision Res 1982;22:341-6.

15. Lewis TL, Maurer D, Brent HP. Optokinetic nystagmus in normal and visually deprived children: implications for cortical development. Can J Psychol 1989;43:121-40.

16. Reed MJ, Steinbach MJ, Anstis SM, Gallie B, Smith D, Kraft $\mathrm{S}$. The development of optokinetic nystagmus in strabismic and monocularly enucleated subjects. Behav Brain Res 1991;46:31-42.

17. Lewis TL, Maurer D, Brent HP. Effects on perceptual development of visual deprivation during infancy. $\mathrm{Br} J$ Ophthalmol 1986;70:214-20.

18. Shawkat FS, Harris CM, Taylor DS, Thompson DA, RussellEggitt I, Kriss A. The optokinetic response differences between congenital profound and nonprofound unilateral visual deprivation. Ophthalmology 1995;102:1615-22.

19. Westall CA, Shute RH. OKN asymmetries in orthoptic patients: contributing factors and effect of treatment. Behav Brain Res 1992;49:77-84. 
20. Westall CA, Eizenman M, Kraft SP, Panton CM, Chatterjee S, Sigesmund D. Cortical binocularity and monocular optokinetic asymmetry in early-onset esotropia. Invest Ophthalmol Vis Sci 1998;39:1352-60.

21. Schoppmann A. Projections from areas 17 and 18 of the visual cortex to the nucleus of the optic tract. Brain Res 1981;223:1-17.

22. Montarolo PG, Precht W, Strata P. Functional organization of the mechanisms subserving the optokinetic nystagmus in the cat. Neuroscience 1981;6:231-46.
23. Hoffmann KP. Optokinetic nystagmus and single-cell responses in the nucleus tractus opticus after early monocular deprivation in the cat. Developmental neurobiology of vision. Boston, MA: Springer US; 1979:63-72.

24. Mohn G, Sireteanu R, Van Hof-van Duin J. The relation of monocular optokinetic nystagmus to peripheral binocular interactions. Invest Ophthalmol Vis Sci 1986;27:565-73.

25. Tychsen L, Lisberger SG. Visual motion processing for the initiation of smooth-pursuit eye movements in humans. J Neurophysiol 1986;56:953-68. 